\title{
THE THEATRE OF THE ABSURD AND JEAN GENET
}

Doç. Dr. Yusuf ERADAM

\section{A New Theatre: Theatre of The Absurd}

The years after the Second World War are the fruitless years for the theatre. But interests were carried towards new subjects and to those of actuality sometimes disguised in the traditional forms and uses. By and by though, without any showy manifestation, another theatre appeared. In 1950s it was imposed upon large audiences, which consisted of intellectuals and students searching for something new, in Theâtre des Noctambules, Theâtre de Poche, Theâtre de la Huchette, Theâtre de Babylone, and Theâtre de Lutece.

The development of this theatre owes much to the successful performance of Ionesco's Rhinoceros at l'Odeon-Theâtre de France, and Arthur Adamov's second play l'Invasion, by Vilar, at Palais de Chaillot. Some of the known directors of these new plays are Georges Vitaly, Andre Reybaz, Roger Blin, Jean-Marie Serrau, and Jaques Mauclair. The actors like Lucien Raimbourg and Tsilla Chelton, and the decorators like Jacques Noel, Rene Allio and Andre Acquart are some of the people equally important in the history of this theatre.

Theatre of the absurd is at first characterized by a deliberate refusal of realism. Although there are moments which carry the traces of the realistic works, realism is never the basic principle. The main principle is to search, on the contrary, in a fundamental unreality which manifests itself as much in the framework as in the intrigue or the characters who oscillate between lack of feeling and nullity and the improbability of the most fantastic sort. The main interest of the playwright is neither to reveal a society and its problems, nor a psychological study, and their refinement is none of their concern either. To create a spectacle they usually tend to constitute an effect of totality which reveals its obsessional interior world through 'gests, songs, light and colors. Thus, it has some 
affinities with the mime, the clowneries (clown-plays), improvisation, the cabaret, and it is like the ritualistic performances of the old Greek plays, such as those of Aristophanes. Besides the comedy and parody of Aristophanes, Commedia dell'arte and vaudville lies in its background.

This new theatre may be called the 'Theatre as Ritual' which 'necessarily seeks a collective experience, because in ritual everyone participates'1. But it is mainly called as the ,Theatre of the Absurd', a term which was first used for the production of Ionesco's La Cuntatrice Chauve (The Bald Soprano) in Paris, in 1950. The Theatre of the Absurd is an expression of individual vision. The spectator may experience that vision too, but what matters is the artist's expression of his vision'.2

The Theatre of the Absurd originated in France; Jean Genet from France, Arthur Adamov born in Russia, Fernando Arrabal from Spanish Morocco, Samuel Beckett from Dublin and Eugene Ionesco from Rumania were the leading figures. It took some of its nourishment from Alfred Jarry's Ubu Roi and Apollanaire's Mamelles de Tiresias which carry some metaphysical implications. Surrealism is considered as the father of the Theatre of the Absurd. ${ }^{3}$ Antonin Artaud, the actor, director, theoretician, and poet is known as the prophet-director of the theatre of the absurd. His production The Cenci, and his secretary Jean-Louis Barrault's production of Franz Kafka's novel The Trial, dramatized by Andre Gide, are perhaps the first and important examples of this theatre. In Barrault's production a 'nameless hero is accused of some never-stated crime, caught up in the machinery of anonymous bureaucracy, and finally executed'.4 Beckett's Waiting for Godot is also a landmark.

What is 'Absurd'? Its dictionary meaning (Longman Dictionary of Contemporary English) is as follows: against reason or common sense; clearly false or foolish; funny because clearly unsuitable or impossible. Martin Esslin, in the introduction to his book The Theatre of the Absurd, adds some cther adjectives: 'out of harmony with reason or propriety; incongruous, ... illogical'. He continues as follows:

1 Barnard Hewitt, History of the Theatre from 1800 to the Present (New York, 1970), p. 167.

2 Hewitt, p. 167-68.

3 It also carries traces frorn futurism, cubism, dadaism and expressionism, and in the 1930s Artaud attempted to give form in his Theatre of Cruelty. 
In common usage, 'absurd' may simply mean 'ridiculous', but this is not the sense in which Camus used the word, and in which it is used when we speak of the theacre of the Absurd. In an essay on Kafka, Ionesco defined his understanding of the term as follows: 'Absurd is that which purpose ... cut off from his religious,' metaphysical, is devoid of and trancendental roots, man is lost; all his actions become senseless, absurd, useless' ${ }^{4}$

Ionesco once defined the absurd as anti-idea, and for this reason some call his theatre 'anti-theatre'. Ionesco's definition quoted by Mr. Esslin reveals a metaphysical anguish at the incongruity, uselessness and senselessness of the human ccndition, and this anguish is the core of the absurdist plays, mainly of Beckett, Adamov, Ionesco, and Genet. This is why theirs is an experimental drama that has attacked timeless issues and problems forever insoluble, 'served by antirealistic production techniques developed for symbolist, expressionistic, theatricalist, and epic theatre.' 5 The definition also displays that absurdity is an existentialist concept, and this clarifies Sartre's interest in and appreciation of the 'crimes' of the absurdists, especially those of Genet. 6

The Theatre of the Absurd, while trying 'to express its sense of the senselessness of the human condition and the inadequacy of the rational approach by the open abandonment of rational devices and discursive thought', ${ }^{7}$ never argues about the subject, but 'it merely presents it in being-that is, in terms of concrete stage images' ${ }^{\prime}{ }^{8}$ The radical but poetic language of it also emerges from these images, 'but what happens on the stage transcends, and often contradicts, the words spoken by the characters'. 9 It finds its most shocking, incantatious, or even devilish expression in Genet's theatre of social protest.

4 Martin Esslin, The Theatre of the Absurd (London, 1964), p. 17. Esslin has taken Ionesco's definition from Dans les Armes de la Ville', Cahiers de la Compagnie Madeleine Renaud-Fean-Louis Barraault, Paris, No. 20, October, 1957.

5 Hewitt, p. 178.

6 Sartre is equally serious in dealing with absurd issues: but he is technically more conventional.

7 Esslin, p. 17.

8 Fsslin, p. 18.

9 Esslin, p. 18. 


\section{Jean Genet: The Villain Or The Saint}

Jean Genet is, 'biographically, the most spectacular author of the twentieth century'.10 He was born in Paris in 1910. His mother, Gabrielle Genet, was a prostitute; and his father is not known. Genet was abandoned by his mother to an orphanage, then he was sent near his peasant foster parents and was brought up by them. Genet learnt about his real family when he got his birth certificate at the age of twenty-one.

He was caught stealing at the age of 10 and was put in a reformatory (maison correctionelle) and stayed there intil he was twentyone. Being accused of theft, he decided to be a thief, and to repudiate a world which repudiated him. ${ }^{11}$ For. a change, he joined French Foreign Legion, but later deserted it, and found male prostitution more appealing to his 'easygoing ways'. Together with homosexuality he was interested in all sorts of crimes. In his books of confessions, Fournal du voleur ${ }^{12}$ (1949), revealing his world of pimps, crooks and murderers, he says: 'Abandoned by my family, I found it natural to aggravate his fact by the love of males, and that love stealing, and stealing by crime, or complicity with crime. 13 ' $\mathrm{He}$ was only twenty when he made his first acquaintance with French prisons. He was arrested in Poland too, while travelling through Europe. When he came to Hitler's Germany he found nothing to destroy:

In Hitler's Germany he felt out of place: 'Even on Unter den Linden $I$ had a feeling of being in a camp organized by bandits .... This is a nation of thieves, $I$ felt. If $I$ steal here, I accomplish no special act that could help me to realize myself. I merely obey the habitual order of things. I do not destroy it.' 14 And so he hastened on into a country that still obeyed the conventional moral code and therefore enabled an outlaw to feel himself outside an established order. ${ }^{15}$

10 Harry T. Moore, Twentietl-Century French Literature (London, 1960) p. 148.

11 Ainsi refusai-je decidemert un monde qui m'avait refuse.' For Sartre this was his existential choice.

12 Sartre called this book Genet's most beautiful work, and ,the Dichtung and Warheit' of homosexuality, that is Goethe's work meaning Literature and Truth':

13 Esslin, p. 152.

14 Jean Genet, Fournal de voleur (Paris: Gaillimard, 1949), p. 131.

15 Esslin, p. 153. 
Genet was made a poet in Fresnes prison while France was under German invasion in 1940. The poem he wrote was 'Condamne a Mort' (Condemned to Death). He also started his first novel Notre-Dame des Fleurs (Our Lady of the Flowers) in 1942 in prison, published in Lyon in 1943. It is a long prose poem, or an epic of the homosexual underground. It has a very fine prose style. It was. written like the poem to Roger Pilorge, who killed his male lover and went to guillotine for that.

His second prose work Miracle de la rose (dated from La sante and Tourelles prisons, 1943) is also about a prisoner talking about his love for a young boy, and the book is a real poetics of homosexuality and burglary.

In Pompes funebres (Funeral Rites, 1945) Genet deals with his own lover who was a member of the resistance against the Nazis. $\mathrm{He}$ left his last prose Querelle de Brest (1946) unfinished. His hero, Querelle, is a murderer who engages in a love affair with the detective trying to solve one of his murders. So 'all these books are in the form of stories set in a world of homosexual outlaws'. ${ }^{16}$

Genet was finally sentenced to life imprisonment because he could not give up his burglaries, but he was set free after the rise of France's literary. world against the sentence.

In 1947 he decided to turn to the theatre and look for 'the logic of the theatre' and achieved his greatest fame in the theatre.

His plays are concerned with expressing his own feeling of helplessness and solitude when confronted with the despair and loneliness of man caught in the hall of mirrors of the human condition, inexorably trapped by an endless progression of images that are merely his own distorted reflection-lies covering lies, fantasies battening upon fantasies, nightmares nourished by nightmares within nightmares. 17

His first play Haute Surveillance (Deathwatch) was staged at the Theâtre des Mathurins in 1949. Les Bonnes (The Maids) his second play was staged by Louis Jouvet at the Athenée. In the next play Le Balcon (The Balcony, 1957) Genet brought 'the theatre to the the-

16 Esslin, p. 153.

17 Esslin, p. 151. 
atre', when it had its premiere on April 22, 1957 in London at the Arts Theatre Club. The plot takes place in Madame Irma's brothel, a house of.mirrors a temple of illusion., where things are truer than life. Madame Irma's brothel is one 'of noble dimension'. Here we have the possibility of experiencing our illusions, of indulging in secret perversions. All the theatrical props are available. Gustomers can play the parts of a bishop, a sado-masochist judge, and others. There is a revolution outside, during which the Queen has been assassinated. George the Chief of Police persuades Mme Irma to play the part of the Queen, and chooses the other members of the Establishment among her customers. 'Thus from playing oút their fantasies reality intrudes.' 18 Revolution fails, George is dissatisfied with his image. When a new revolution breaks Irma returns to her old task as brothel-keeper. 'What the brothel does is give men a presentment of their dreams in their essential meaning. ${ }^{19}$ It is a play which strips a.way the mask of the society itself, by giving a close analysis of it. This analysis reflects the workings of the society as false. He projects

the feeling of impotence of the individual caught up in the meshes of society, he is dramatizing the often suppressed and subconscious rage of the ' $\mathrm{I}$ ' alone and terrified by the anonymous weight of the nebulous 'they'. It is this helplessness, this impotence, that seeks an outlet in the substitute explanation of myth and daydreams.' 20

The characters try to bring back the reality of the universe but they always fail, for Genet's message is that reality is unattainable for he has no control over it. The play represents 'a world of fantasy about a world of fantasy'21 which seems absurd. Genet's The Balcony' is an example of the Theatre of the Absurd as well as the theatre as ritual. The ritual in the play is 'the regular repetition of mythical events. and, as such, closely akin. to sympathetic magic'22. This is Genet's basic dilemma.

Genet calls The Blacks (Les Negres) a 'clown show'. It presents a 'true picture born of a clistorted image'. The play was first performed

18 Frederick Lumley, New'Trends in. Tiventieth-Century Drama (New York, 1972), p.216.

19 Harold Clurman, The Jaked lmage (New York, 1958), p. 72.

20 Esslin, p. 167.

21 Essin, p. 166.

22 Esslin, p. 169. 
by a group of Negro actors, Les Griots, under the direction of Roger Blin, at the Theâtre de Lutèce on October 28, 1959. Genet uses splendid colors provoking frightened laugh, and avoids the emergence of sentiment. The play is usually considered as a perfect crime. The blacks are the symbol of all the scorned, neglected, oppressed, ridiculed people thrust out by the society. Thus Genet does not put any plea for an end of racism, or for better treatment of the Negroes, but he projects an elaboration of Negro frantasies about white people.

Les Paravents (The Screens, 1961) is a disturbing comment on the Algerian war. It was.first staged in Berlin. It is about the battle of Algerians against the powers and authorities. The action takes place in front of a number of screens ten feet high with landscapes and various objects painted on them displaying the scenes for the action. Genet in the stage directions wants the actors to wear masks or to be garbed in excessive clothing wearing false noses or chins. It is a reflection of a concrete brutal world which leaves the authorities and the audience deeply disturbed.

Genet's mind moves from image to image, and not from idea to idea. His genius is anarchic, resisting against intellectual organization. The images pile up, some of them memorable, others merely capricious; meanwhile the argument stands still..

Evil is sanctified in Genet's works. This is the black magic aspect of Genet's art. 'C'est l'enfer qui est le paradis': In his works hell is reflected as heaven.

Another originality of Genet lies in his fashion to suggegt, by the play of mirrors and of reflections all of which are but illusions; the world of appearances is always purer and more seducing than reality. Genet's reality necessarily includes society by his inversion of it. He conceals the two great forces which motivate all men: sex and the will to power. They both have the same roots for Genet, and sex to him is, a matter of domination and submission'.23

The Man, the Woman, the attitude and the word which in real life seem abject; in the theatre must fill the audience with wonder, without exception, must always astonish by their elegance and their obviousness. ${ }^{24}$

23 Esslin, p. 166.

24 Jcan Genct, Lelles to Roger Blinr: Reflections 1 in the Theater. trans. by Riclaard Scaver (New York, 1969), p. 36. 
To Genet theater should present the vulgar, the horrible and the obscene, through rich and rhythmic language and gestures within the framework of Black Mass. 'The greatest hero for him is the greatest criminal, the greatest , rebel against society.' $25 \mathrm{He}$ uses language as a means to communicate the spectator the harsh facts of this cruel world and his own isolation. For Genet, theatre assumes a religious role, and turns out to be a. Dionysian nightmare. He lived and died like the hero of such a nightmare, a committed antagonist.

\section{Bibliography}

Bersani, J. and others.: La Litterature en France depuis 1945. Paris, 1970.

Bonnefoy, Claude.: Jean Genet. Paris, 1965.

Brereton, Goeffrey.: A Short History of French Literature. Harmondsworth, 1954.

Clurman, Harold.: The Naked Image. New York, 1958.

Esslin, Martin.: The Theatre of the Absurd. London, 1964.

Genet, Jean.: The Balcony. Bernard Frechtman (trans). New York, 1966.

.: The Blacks. Bernard Frechtman (trans). New York 1960.

.: Funeral Rights. Bernard Frechtman (trans). New. York, 1969 .

: Letters to Roger Blin: Reflections on the Theatre. Richard Seaver (trans). New York, 1969.

.: The Maids and Deathwatch. Bernard Frechtman (trans). New York, 1961. 1962.

Hewitt, Barnard.: History of the Theatre from 1800 to the Present. New York, 1970.

Jaçquart, Emmanuel.: Le Theâtre de derision. Paris, 1974.

Lumley, Frederick.: New Trends in Twentieth-Century French Literature. London, 1966.

25. Hewitt, p. 163. 
Moore, Harry T.: Twentieth-Century Frınch Literature. London, 1960.

Sartre, Jean Paul.: Saint Genet: Comedien et Martyr. Paris, 1952.

Serrau, Geneviéeve.: Histoire du "Nouveau theatre". Paris, 1966.

Şener, Sevda.: Dünder Bugüne Tiyatro Düşüncesi. İstanbul, 1982.

Stynan, J.L.: The Dark Comedy: The Development of Modern Comic Tragedy. Michigan, 1961.

Williams, Raymond.: Drama from Ibsen to Brecht.. Harmordsworth, 1978. 